$$
\begin{array}{ll}
\text { УДК } & 159.942-057.87 \\
& 316.46-057.87 \\
& 005.322: 316.46-057.87 \\
\text { COBISS.SR-ID 513529781 }
\end{array}
$$

https://doi.org/10.18485/fb_godisnjak.2019.11

\title{
СТРУКТУРА ЕМОЦИОНАЛНЕ ИНТЕЛИГЕНЦИЈЕ И ЛИДЕРСТВА СТУДЕНАТА ФАКУЛТЕТА БЕЗБЕДНОСТИ И УЧИТЕЉСКОГ ФАКУЛТЕТА
}

Виолета Тадић", студенткиња докторских студија Универзитет у Београду, Факултет безбедности 



\section{СТРУКТУРА ЕМОЦИОНАЛНЕ ИНТЕЛИГЕНЦИЈЕ И ЛИДЕРСТВА СТУДЕНАТА ФАКУЛТЕТА БЕЗБЕДНОСТИ И УЧИТЕЉСКОГ ФАКУЛТЕТА}

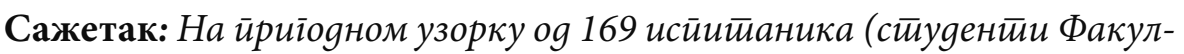

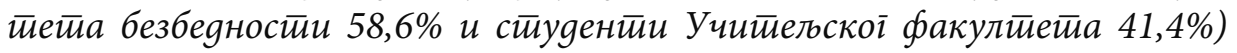
исииитана је йовезаности емоционалне иниеелиіенције и лияерсиива. Ис-

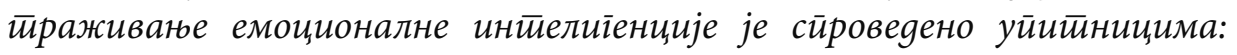
Уйитиник емоиионалне интиелиіенције, УЕК-45, УЕК-15, УЕРК. Истираживаюе лияерстива је сировеgено уйитиником који су конситруисали ау-

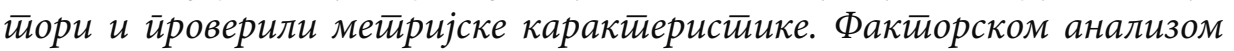

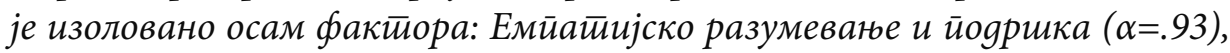

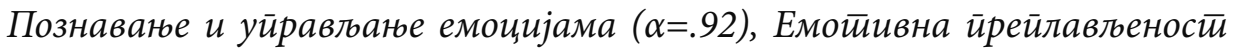
$(\alpha=.86)$, Лияерсииво ( $\alpha=.89)$, Чийаюе емоција ( $\alpha=.85)$, Уйравльюье льуима

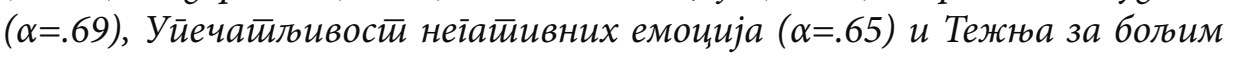
gелованем ( $\alpha=.66)$. Лияерстиво йозиииивно корелира са иири комйонениете емоционалне иниеелиіенције - Емйайијским разумеванем и йодриком $(r=.56)$, Познаватем и уирављағем емоцијама $(r=.51)$ и Чийағем емо-

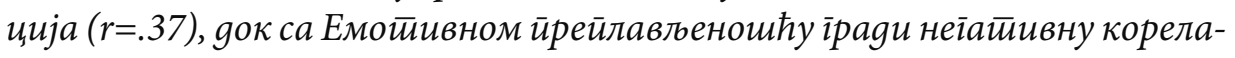

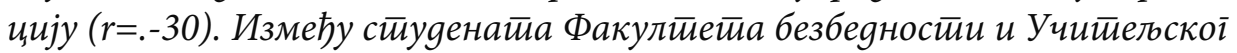
факулиметиа нису уйврђене стиайистички значајне разлике.

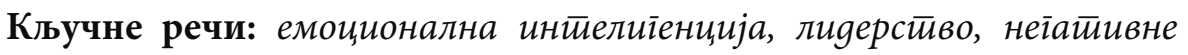
емоције, емйайија, чийане емоиија. 


\section{Увод}

Последњих година, нарочито у вези са развојем теорије менаџмента, често се поставља питање шта је то што неке особе чини успешним лидерима. Општеприхваћен, али погрешан став јесте да је успех одређен само когнитивном интелигенцијом. Наиме, наша култура и образовни систем ослањају се искључиво на стечена академска знања и способности, вреднујући и успех младих на основу њих. На тај начин се занемарује низ других компетенција, које су од пресудног значаја како за образовање, тако и за каснији успех у животу.

Како бисмо разумели „где је пут ка срећи“ и због чега једна особа у животу напредује, а друга не, важно је разумети улогу и значај емоционалне инйелиіенције. Конструкт емоционалне интелигенције појавио се у психолошкој литератури деведесетих година прошлог века. Овим конструктом истраживачи су настојали да открију психичке процесе који су укључени у обраду емоционалних информација. Првобитно, емоционална интелигенција дефинисана је као „способност праћења својих и туђих осећања и емоција и употреба тих емоција у размишљању и понашању“ (Salovey \& Mayer, 2000). Међутим, овакав начин дефинисања емоционалне интелигенције наглашавао је само опажање и регулацију емоција, занемарујући размишљање о њима. Тако аутори касније предлажу ревидирану дефиницију, по којој „емоционална интелигенција укључује способности брзога запажања, процене и изражавања емоција; способност увиђања и генерисања осећаја који олакшавају мишљење; способности разумевања емоција и знање о емоцијама; и способност регулисања емоција у сврху промоције емоционалног и интелектуалног развоја“ (Mayer \& Salovey, 1997, према Takšić, Mohorić, \& Munjaš, 2006). На основу наведеног, емоционална интелигенција се показала као конструкт који је подстакао свест о значају емоција.

Када је у питању операционализација и валидација конструкта емоционалне интелигенције, тај процес још увек није завршен. Међутим, потребно је осврнути се на резултате који су проистекли из истраживања датог појма. Досадашњим истраживањима је утврђено постојање различитог броја фактора емоционалне интелигенције. Петридес и Фурнам (Petrides \& Furnham, 2001) су добили структуру коју чине четири фактора: Оптимизам (склоност да се очекује најбољи исход чак и у неповољним ситуацијама), Процена емоција (способност препознавања, процене и разликовања емоција), Социјалне вештине (способност представљања себе као кооперативног, корисног и конструктивног члана групе) и Корист од емоција (способност прилагођавања емоција, 
мисли и понашања у променљивим условима). Одређени аутори, пак, заступају трофакторску структуру, која обухвата: Идентификацију емоција (способност запажања емоција код себе и других људи, у њиховом физичком стању), Разумевање емоција (способност разумевања емоционалних информација, повезаности међу емоцијама и размишљање о њиховом значењу) и Управљање емоцијама (отвореност за осећања, контрола емоција код себе и других у циљу личног разумевања и раста) (Matthews, Zeidner, \& Roberts, 2002; Livingstone \& Day, 2005).

Лидерство је веома сложена појава и изражено заступљена као истраживачка тема, па се сусрећемо са великим бројем дефиниција лидерства. Једна од њих лидерство дефинише као „способност једног појединца да утиче, мотивише и оспособи друге да доприносе учинку и успеху организације“ (House, Spangler, \& Woycke, 1991, према Hajncl, 2012). Лидерство се данас углавном везује за понашања и више представља улогу него саму функцију, тј. формални положај.

Комбинацијом различитих теорија лидерства добијени су одређени елементи који представљају предуслов успешног лидерства. Ти елементи се односе на: развијање колективног осећаја важности остварења циљева организације, преношење ставова о поштовању радних активности, одржавање оптимизма, сарадње и поверења у организацијама, подстицање флексибилности приликом доношења одлука, итд. (George, 2000).

Постоји пет главних приступа истраживању лидерства: приступ особина личности, бихејвиорални, приступ моћ-утицај, ситуациони и интегративни. Најзаступљенији је бихејвиорални приступ, који нагласак ставља на проучавање рада лидера кроз опис његових понашања у организацији, начина на који доноси одлуке и комуницира, не процењујући његова обележја. У литератури се често истиче да је главна разлика између ефективних и неефективних лидера управо у њиховом понашању (Stogdili \& Cons, 1956, према Halpin, 1956).

Нови приступ вођењу указује на важност емоција у процесу лидерства. Емоције су повезане са мотивацијом, тј. односом према послу, као и међуљудским односима. Стога се сматра да је емоционална интелигенција значајан саставни део лидерства. Популарност емоционалне интелигенције везује се за рад у непосредној сарадњи са другима, у окружењу које се константно и брзо мења, при чему се ствара све већа потреба за социјално прихватљивим начином превладавања тешкоћа (Ashforth \& Humphrey, 1995; Ashkanasy, Hartel, \& Zerbe, 2000). У складу са тим, емоционална интелигенција се сматра главним квалитетом успешног лидеpa (Cooper, 1997; Goleman, 1998), важном компонентом комуникације 
унутар тима (Yost \& Taker, 2000), фактором који доприноси бољим перформансама (Abraham, 1999) и битним елементом пословне едукације (Tucker, Sojka \& Barone, \& McCarthy, 2000).

Евалуационе студије које се баве испитивањем повезаности емоционалне интелигенције и лидерства показују како ниво емоционалне интелигенције утиче на успех у вођењу и прави разлику између просечних и изврсних руководилаца. Тако је Меклиланд (McClelland, 1998) у свом истраживању дошао до закључка да постоји одређена граница изражености емоционалних компетенција која пружа могућност разликовања изузетних од просечних менаџера. Како би се изврсни менаџери разликовали од просечних, потребно је да овладају са минимум шест емоционалних компетенција. Истраживање које је наредне године спровео Бојазис само се ослања на истраживање Меклиланда и показује да што више изражених компетенција особа поседује, разлика између просечног и изузетног менаџера је већа (Boyatzis, 1999). Бојазис је, такође, утврдио да саморегулација има највећи утицај на успех у послу. На основу истраживања које су спровели Сласки и Картврајт (Slaski \& Cartwright, 2003), а које се бавило питањем утицаја емоционалне интелигенције на управљање емоцијама у стресним ситуацијама на послу, закључено је да руководиоци који имају висок ниво емоционалне интелигенције процењују мањим стрес који доживљавају на послу.

Када је реч о значају емоционалне интелигенције у процесу регрутовања, селекције и едукације запослених, Бенсон, Зигарни и Нимон (Benson, Zigarni, \& Nimon, 2012) су спровели посебно истраживање. Фокус њиховог истраживања био је на утврђивању везе између самопроцене емоционалне интелигенције код руководилаца и процене њиховог понашања од стране запослених. На основу резултата истраживања је закључено да ће руководиоци који поседују виши степен емоционалне интелигенције у већој мери практиковати примену подржавајућих понашања у односу са подређенима.

У овом истраживању жели се испитати повезаност лидерства, као диспозиције унутар личности, и различитих компоненти емоционалне интелигенције. Употребом два инструмента који мере емоционалну интелигенцију, на пригодном узорку студената жели се утврдити каква структура емоционалне интелигенције ће се добити и како ће поједине компоненте бити повезане са лидерством. 


\section{Метод истраживања}

Спроведено је експлоративно истраживање, са циљем да се утврди повезаност емоционалне интелигенције и лидерства код студената. Истраживање је рађено употребом упитника. У анализи података коришћена је факторска анализа.

\section{Узорак}

Истраживање је рађено на пригодном узорку студената Факултета безбедности $(58,6 \%)$ и Учитељског факултета $(41,4 \%)$. У истраживању је учествовало 169 испитаника, од којих су 72,8\% биле студенткиње и $27,2 \%$ студенти. Старост испитаника се кретала од 19 до 25 година $(\mathrm{AS}=20,88)$.

\section{Инсӣруменйи}

Истраживање је спроведено употребом упитника, са петостепеном Ликертовом скалом, који мере варијабле емоционалне интелигенције и лидерства. За истраживање емоционалне интелигенције коришћено је више инструмената: Упитник емоционалне интелигенције (Radosavljević i Đorđević, 2016) који мери пет варијабли (самосвесност, самоконтрола, самомотивација, емпатија, социјалне вештине), Упитник емоционалне компетентности (УЕК-45; Такшић, 2002), Упитник емоционалних вештина и компетентности (УЕК-15; Такшић, 2002) и Упитник емоционалне регулације и контроле (УЕРК; Такшић, 2003). За истраживање лидерства конструисана је скала за ову намену.

\section{Резулй $а \bar{u} и$}

\section{Факйорска анализа}

Факторском анализом резултата добијених на свим тврдњама упитника, методом главних компоненти (са Promax ротацијом и Kaiser нормализацијом), изоловано је осам фактора који објашњавају укупно 48,697\% варијансе (редом објашњавају 21,575\%, 6,491\%, 4,647\%, 4,240\%, 3,503\%, $3,097 \%, 2,747 \%$ и 2,397\%). Анализа поузданости (Кронбахов алфа коефицијент) показује да првих пет фактора имају веома високе и високе поузданости ( $\mathrm{a}=0.937, \mathrm{a}=0.923, \mathrm{a}=0.867, \mathrm{a}=0.894, \mathrm{a}=0.854)$, а последња три 
средње поузданости $(\mathrm{a}=0.695, \mathrm{a}=0.654, \mathrm{a}=0.662$. Резултате добијене употребом последња три фактора треба узети у обзир са великом резервом.

Факторима су дата следећа имена: Емпатијско разумевање и подршка, Познавање и управљање емоцијама, Емотивна преплављеност, Лидерство, Читање емоција, Управљање људима, Упечатљивост негативних емоција и Тежња за бољим деловањем.

У оквиру фактора Емйайијско разумевате и йоgрика груписале су се тврдње које се односе на емоционалну повезаност са другима и разумевање њихових осећања и потреба („Покушавам да помогнем и разумем потребе и осећања других људи“ [.765], „Добар сам слушалац“ [.767], „Код пријатеља могу разликовати када је тужан, а када разочаран“ [.639]), затим разумевање и поштовање различитих перспектива и погледа на свет, поштовање и награђивање постигнућа других људи („Показујем осетљивост и разумевање за перспективе других“ [.731], „Признајем и награђујем код људи њихову предност, постигнућа и развој“ [.80]), као и постојање свести о својим вредностима, циљевима, искуствима, осећањима и њиховом утицају на будуће деловање („Из неугодних искустава учим како се убудуће не треба понашати“ [.624]).

Фактор Познаваюе и уиравтағе емоиијама окупља тврдње које представљају индикатор способности препознавања, процене и изражавања својих емоција, разумевања емоција и размишљања о њима, као и управљања својим и туђим емоцијама, потискујући негативне, а подстичући позитивне. Тврдње које су показале највише засићење фактора су: „Могу добро изразити своје емоције (.911), „Могу описати како се осећам“ (.886), „Лако могу набројати емоције које тренутно доживим“ (.863).

Трећи фактор, Емотиивна йрейлављености, представља недостатак суздржаности и емоционалне самоконтроле, односно неспособност одржавања емоционалне стабилности, управљања својим унутрашњим емотивним стањем и импулсима, као и немогућност заустављања и преобликовања неприкладних аутоматских реакција. Тврдње које показују највеће засићење фактора су: „Моји су осећаји понекад изван моје контроле“ (.695), „Расположење ми снажно утиче на размишљање“ (.646), „Када се јако разбесним, као да ми 'падне мрак на очи'“ (.589).

Четврти фактор, Лияерсииво, описује способност да се преузме руководећа улога у тиму и спремност на деловање како би се путем личног залагања и сарадње постигао заједнички успех. Тврдње које имају највише засићење фактора су: „Спреман сам да преузмем организацију времена како би тим био успешнији“ (.862), „Спреман сам да утичем на друге људе ради стварања успешног тима“ (.847), „Спреман сам да разлажем сложене пројекте у мање изводљиве задатке да би тим био успешнији (.740). 
Пети фактор, Читиаюе емоција, обухвата тврдње које се односе на способност запажања и процене емоција код других особа, у њиховом физичком стању („Могу запазити када се неко осећа беспомоћно“ [.707]), као и разликовање искреног од неискреног изражавања емоција („Приметим када неко настоји прикрити лоше расположење“ [.689], „Приметим када неко прикрива своје праве осећаје“ [.616]).

Шести фактор, Уйрављаюе љуgима, укључује поступке усмерене на способност одржавања односа, што доводи до бољих веза са другима и побољшава комуникацију. У конкретном случају се односи на вештину убеђивања, утицај и комуникацију („Добар сам у креирању драматичних догађаја како бих ефективно доказао поенту“ [.688], „Осећам се добро кад управљам људима“ [.650]).

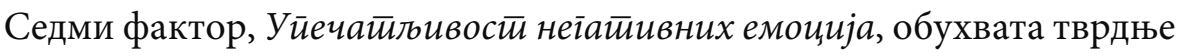
које се односе на процену утицаја негативних емоција и расположења на памћење („Посебно добро се сећам тренутака у којима сам био жалостан“[.761], „Најбоље се сећам догађаја уз које ме вежу негативне емоције“ $[.675])$.

Осми фактор, Тежна за бољим деловањем, укључује активне поступке који усмеравају и одржавају жељено понашање у сврху постизања циља. Тврдње које остварују највишу засићеност фактора су: „Континуирано учим у циљу побољшања свог деловања“ (.574), „Обавезе и задатке радије одмах извршим, него да о њима мислим“ (.547).

\section{Дескриптивна статистика према изолованим факторима}

У Табели 1. приказани су дескриптивни показатељи изолованих фактора. Највећу израженост показују Емпатијско разумевање и подршка $(\mathrm{AS}=4.23)$ и Лидерство ( $\mathrm{AS}=4.13)$, док је у најмањој мери изражена Емотивна преплављеност ( $\mathrm{AS}=2.65)$, као и Упечатљивост негативних емоција $(\mathrm{AS}=2.90)$. Што се осталих димензија тиче, високо и умерено су изражене: Познавање и управљање емоцијама $(\mathrm{AS}=3.83)$, Тежња за бољим деловањем $(\mathrm{AS}=3.79)$, Читање емоција ( $\mathrm{AS}=3.67)$ и Управљање људима $(\mathrm{AS}=3.12)$.

Између студената Факултета безбедности и Учитељског факултета нису утврђене статистички значајне разлике. На основу резултата, утврђено је постојање статистички значајних разлика према полу, и то за Емотивну преплављеност (м=2,507; ж=2,715) и Лидерство (м=4,256; ж=3,952). 
Табела 1. Дескриптивна статистика фактора

\begin{tabular}{|l|c|c|c|c|}
\hline & Min & Max & AS & St. Dev. \\
\hline Емпатијско разумевање и подршка & 2,04 & 5,00 & 4,23 & 0,523 \\
\hline Познавање и управљање емоцијама & 2,10 & 5,00 & 3,84 & 0,646 \\
\hline Емотивна преплављеност & 1,28 & 4,39 & 2,66 & 0,611 \\
\hline Лидерство & 2,00 & 5,00 & 4,03 & 0,714 \\
\hline Читање емоција & 2,36 & 5,00 & 3,68 & 0,552 \\
\hline Управљање људима & 1,50 & 5,00 & 3,12 & 0,710 \\
\hline Упечатљивост негативних емоција & 1,25 & 4,75 & 2,90 & 0,703 \\
\hline Тежња за бољим деловањем & 1,80 & 5,00 & 3,79 & 0,645 \\
\hline
\end{tabular}

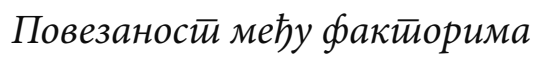

Повезаности међу факторима су углавном средње или ниске. У даљем тексту, биће коментарисано само првих пет фактора који показују високу поузданост. Лидерство гради средње повезаности са Емпатијским разумевањем и подршком и Познавањем и управљањем емоцијама и ниске повезаности са Емотивном преплављеношћу (негативна повезаност) и Читањем емоција. Добијени резултати потврђују повезаност лидерства као особине личности са емоционалном интелигенцијом, која је у овом истраживању разложена на четири горе наведене компоненте.

Табела 2. Корелације међу факторима

\begin{tabular}{|c|c|c|c|c|c|c|c|}
\hline & 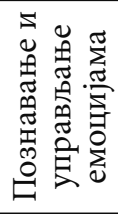 & 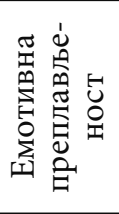 & 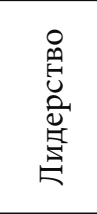 & 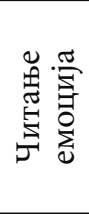 & 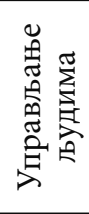 & 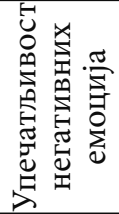 & 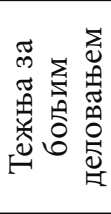 \\
\hline $\begin{array}{c}\text { Емпатијско } \\
\text { разумевање и } \\
\text { подршка }\end{array}$ & $.633^{*+*}$ & $-.278^{* \star}$ & $.559^{* *}$ & $.465^{* *}$ & $.184^{*}$ & -.080 & $.590^{* *}$ \\
\hline $\begin{array}{c}\text { Познавање и } \\
\text { управљање } \\
\text { емоцијама }\end{array}$ & & $-.257^{* *}$ & $.510^{* *}$ & $.478^{* *}$ & .137 & -.042 & $.435^{* *}$ \\
\hline $\begin{array}{c}\text { Емотивна } \\
\text { преплављеност }\end{array}$ & & & $-.302^{* *}$ & -.076 & .121 & $.279^{* *}$ & $-.250^{* *}$ \\
\hline Лидерство & & & & $.365^{* *}$ & $.276^{* *}$ & -.101 & $.381^{* *}$ \\
\hline Читање емоција & & & & & $.274^{* *}$ & .034 & $.252^{* *}$ \\
\hline $\begin{array}{c}\text { Управљање } \\
\text { људима }\end{array}$ & & & & & & $.240^{* *}$ & $.214^{* *}$ \\
\hline $\begin{array}{c}\text { Упечатљивост } \\
\text { негативних } \\
\text { емошиіа } \\
\end{array}$ & & & & & & & .059 \\
\hline
\end{tabular}

Найомена: ${ }^{\star} \mathrm{p}<.05,{ }^{* *} \mathrm{p}<.01$ 
Висока повезаност добијена је између Емпатијског разумевања и подршке и Познавања и управљања емоцијама, а дати фактори граде средњу повезаност са Читањем емоција и ниску негативну повезаност са Емотивном преплављеношћу.

\section{Дискусија}

Бројним истраживањима доказано је да емоције, ако се њима правилно управља, могу поспешити рационално размишљање, омогућити исправно доношење одлука и усмерити појединца на одговарајуће понашање (Михајлов и Михајлов, 2010). Такви налази су значајни за разумевање лидерства и повезаности са емоционалном интелигенцијом. Ово истраживање је потврдило повезаност емоционалне интелигенције и лидерства и утврдило посебне повезаности између појединих фактора емоционалне интелигенције и лидерства. Издвојена су четири поуздана фактора емоционалне интелигенције: Емпатијско разумевање и подршка, Познавање и управљање емоцијама, Емотивна преплављеност, Читање емоција и три мање поуздана фактора: Управљање људима, Упечатљивост негативних емоција и Тежња за бољим деловањем.

Добијена структура емоционалне интелигенције се делимично поклапа са трофакторским моделом емоционалне интелигенције, уколико се доведу у везу факторе Емпатијско разумевање и подршка, Познавање и управљање емоцијама и Читање емоција, у нашем моделу, са факторима Разумевање емоција, Управљање емоцијама и Идентификација емоција, у трофакторском моделу (Matthews, Zeidner, \& Roberts, 2002; Livingstone \& Day, 2005). Специфичност добијеног модела је што детектује Емотивну преплављеност као посебан фактор, који је негативно повезан са осталим факторима емоционалне интелигенције.

Добијени модел се слабо поклапа са моделом Петридеса и Фурнама (2001), због тога што се не види јасна повезаност са факторима Оптимизам и Корист од емоција. Евентуално се Емотивна преплављеност може посматрати као фактор са супротним предзнаком у односу на Корист од емоција. Повезаност се може тражити између фактора Процена емоција и, у нашем моделу, Читање емоција, те фактора Социјалне вештине и Лидерство, у нашем истраживању. Тиме се отвара нов концептуални проблем, да ли је лидерство једна од компоненти емоционалне интелигенције или је треба посматрати као засебну особину личности. Кад се спроведе факторска анализа другог реда на добијеним факторима овог 
истраживања, лидерство се уклапа у структуру емоционалне интелигенције. То још увек није довољан разлог да се лидерство посматра као компонента емоционалне интелигенције, већ говори о великом значају емоционалне интелигенције за сналажење у међуљудским односима, генерално гледано, а посебно када је вођство у питању.

Резултати овог истраживања показују да је Лидерство повезано са свим факторима сем са Упечатљивошћу негативних емоција, што је од слабог значаја, пошто је реч о недовољно поузданом фактору. Позитивне повезаности се остварују са Емпатијским разумевањем и подршком, Познавањем и управљањем емоцијама и Читањем емоција, док се негативна повезаност остварује са Емотивном преплављеношћу. На основу тога се може закључити да је израженост особине лидерства повезана са разумевањем емотивних стања других особа и бољим сналажењем у међуљудским односима, који захтевају контролу властитих и туђих емоција. И ранија истраживања потврђују повезаност лидерства и емоционалне интелигенције (McClelland, 1998; Slaski \& Cartwright, 2003; Benson, Zigarni, \& Nimon, 2012). Емпатијско разумевање и подршка јесте компонента емоционалне интелигенције значајна за лидерство, јер се захваљујући тој компетенцији лидер боље сналази у контакту са људима са којима сарађује, боље утиче на њих и усмерава их у складу са својим запажањима. Дати налази се поклапају са налазима сличних истраживања (George, 2000; Mayer, Salovey, Caruso, \& Cherkasskiy, 2011), која показују да особе које имају развијену способност познавања и управљања емоцијама лакше спроводе лидерство у међуљудским односима.

Изражено лидерство је повезано са компонентом Читање емоција. Способност да се опазе, именују и дају значења емоцијама саставни је део компоненте Читање емоција, која укључује низ посебних способности, као што су препознавање израза лица, говора тела, тона гласа и слично. Развијено читање емоција је неопходно за управљање људима, јер без доброг и адекватног начина опажања емоција других људи није могуће ни адекватно реаговати у социјалним односима (Mayer et al., 2011). Способност доброг опажања емоција је праћена и већом могућношћу испитаника да “уђе у ципеле” оног другог и да разуме различита емоционална стања. С друге стране, немогућност опажања емоција код других би директно онемогућила и разумевање истих, а самим тим и успостављање добрих односа заснованих на ефективној комуникацији и сарадњи.

Резултати овог истраживања показују да је изражено лидерство повезано са мањом Емотивном преплављеношћу. То се поклапа са резултатима студија које доводе у везу емоционалну контролу и лидерство 
и истичу да способност контроле емоција омогућава вођи да се носи са стресом, фрустрацијама и разочарењима (Mayer et al., 2011; Downey, Papageorgiou, \& Stough, 2005).

Емотивна преплављеност је, поред наведеног, повезана са слабије израженим Емпатијским разумевањем и подршком и Познавањем и управљањем емоцијама. Емотивна преплављеност, као и анксиозност, негативно утиче на когнитивне процесе и стога слаби квалитет и интензитет опажања и разумевања социјалног света и социјалних односа. Поред тога што се одражава на односе са другима, слаби и мотивацију за рад.

Интересантно је да на испитаном узорку жене показују израженију емотивну преплављеност, а мушкарци израженије лидерство. Дати резултати могу се довести у везу са чињеницом да се ради о пригодном узорку. У супротном, ако се закључци генерализују на популацију, може се рећи да је код жена више изражена емотивна преплављеност, што спутава њихово сналажење у социјалном свету, док су мушкарци спремнији да преузму руководећу улогу у тиму и показују већу тежњу ка заједничком успеху кроз лично залагање и сарадњу. Низак резултат мушкараца на емотивну преплављеност може се разумети тенденцијом да се дају нижи одговори на тврдње ове скале због тога што се дата особина традиционално посматра као слабост и жели да се прикрије. Према родно заснованим стереотипима, жене су означене као „природно“ лошији лидери, емоционално топлије (срдачније) и нестабилније, док су се стереотипи у погледу ефективног лидерства, поред чињенице да мушкарци воле да буду лидери, што је показало и наше истраживање, поклапали са стереотипима да су они компетентнији, жилавији и мање топли (Baliñska, 2007, према Górska, 2016; Bass, 1981; Powell \& Butterfield, 1989).

\section{Закључак}

Овим истраживањем настојано је испитати повезаност лидерства и емоционалне интелигенције. Употребом два инструмента који мере емоционалну интелигенцију утврђена је структура емоционалне интелигенције, а затим је испитана повезаност појединих компоненти са лидерством. Издвојена су четири поуздана фактора емоционалне интелигенције, који уједно у нашем истраживању представљају компоненте на које је емоционална интелигенција разложена (Емпатијско разумевање и подршка, Познавање и управљање емоцијама, Емотивна преплављеност, Читање емоција) и три мање поуздана фактора (Управљање људи- 
ма, Упечатљивост негативних емоција и Тежња за бољим деловањем). Истраживање је потврдило повезаност лидерства и емоционалне интелигенције. Показало се да што је код испитаника више изражена црта вођења, тј. лидерство, то су више изражене три компоненте емоционалне интелигенције: Емпатијско разумевање и подршка, Познавање и управљање емоцијама и Читање емоција. Такође, показало се да лидерство гради негативну повезаност са Емотивном преплављеношћу. На основу тога може се закључити да је израженост особине лидерства повезана са разумевањем емотивних стања других особа и бољег сналажења у међуљудским односима, који захтевају контролу властитих и туђих емоција. Такође, развијено Читање емоција је неопходно за управљање људима. Могућност особе да се стави у позицију других особа, да ствари посматра из њихове перспективе и да на адекватан начин опажа, именује и даје значења емоцијама, у значајној мери доприноси успостављању бољих међуљудских односа и сарадње. 


\section{ЛИТЕРАТУРА}

Abraham, R. (1999). Emotional intelligence in organizations: A conceptualization. Genetic, Social, and General Psychology Monographs, 125(2), 209-224.

Ashforth, B. E., \& Humphrey, R. H. (1995). Emotion in the workplace: A reappraisal. Human relations, 48(2), 97-125.

Ashkanasy, N. M., Härtel, C. E. J. \& Zerbe, W. J. (2000). Emotions in the Workplace: Research, Theory, and Practice. In: Ashkanasy, N. M., Härtel, C. E. \& Zerbe, W. J. (Eds.), Emotions in the workplace: Research, theory, and practice. Westport: Quorum Books/Greenwood Publishing Group, 3-18.

Bass, B. M. (1981). Stogdill's Handbook of Leadership. New York: Free Press.

Benson, J., Zigarni, D. \& Nimon, K. (2012). Manager's Emotional Intelligence, Their Perceived Use of Directive and Supportive Leader Behaviors and Resultant Employee Satisfaction. Journal of Business Administration Research, 1, 30-50.

Cooper, R. K. (1997). Applying emotional intelligence in the workplace. Training and Development, 51(12), 31-38.

Downey, L., Papageorgiou, V. \& Stough, C. (2005). Examining the relationship between leadership, emotional intelligence and intuition in senior female managers. LODJ, 27(4), 250-264.

George, J. M. (2000). „Emotions and leadership: the role of emotional intelligence“. Human Relations, 53, 1027-1055.

Goleman, D. (1998). What makes a leader? Harvard Business Review, 76(6), 93-102.

Górska, A. (2016). Gender Differences in Leadership. Studia i Materiaïy, $1(20), 136-144$.

Hajncl, Lj. (2012). Emocionalna inteligencija i stilovi rukovođenja. Doktorski rad. Zagreb: Odsjek za psihologiju Filozofskog fakulteta u Zagrebu.

Halpin, A. W. (1956). The Behaviors of Leaders. Educational Leadership, 14, 172-176.

Livingstone, H. A. \& Day, A. (2005). Comparing the Construct ande CriterionRelated Validity of Ability-Based and Mixed-Model Measures of Emotional Intelligence. Educational and Psychological Measurement, 65, 757-779.

Mayer, J. D., Salovey, P., Caruso, D. R. \& Cherkasskiy, L. (2011). „Emotional intelligence“. In: Sternberg, R. J. \& Kaufman, S. B. (Eds.), The Cambridge handbook of intelligence. New York: Cambridge University Press, 528-549. 
Matthews, G., Zeidner, M. \& Roberts, R. D. (2002). Emotional Intelligence: Science \& Myth. A Bradford Book. Cambridge: The MIT Press.

McClelland, D. C. (1998). Identifying competencies with behavioral-event interviews. Psychological Science, 9(5), 331-340.

Petrides, K.V.\&Furnham, A. (2001). Traitemotionalintelligence:Psychometric investigation with reference to established trait taxonomies. European journal of personality, 15(6), 425-448.

Powell, G. N. \& Butterfield, D. A. (1989). The "good manager": Did androgyny fare better in the 1980s? Group and Organization Studies, 14(2), 216-233

Salovey, P. \& Mayer, J. D. (1990). Emotional intelligence. Imagination, Cognition and Personality, 9, 185-211.

Slaski, M. \& Cartwright, S. (2003). Emotional intelligence training and its implications for stress, health and performance. Stress and Health, 19, 233-239.

Tucker, M. L., Sojka, J. Z., Barone, F. J., \& McCarthy, A. M. (2000). Training tomorrow's leaders: Enhancing the emotional intelligence of business graduates. Journal of Education for Business, 75(6), 331-337.

Yost, C. A. \& Tucker, M. L. (2000). Are effective teams more emotionally intelligent? Confirming the importance of effective communication in teams. Delta Pi Epsilon Journal, 42(2), 101.

Михајлов, С. и Михајлов, Н. (2010). Утицај емоционалне интелигенције на успешност руковођења. БизИнфо, 1, 71-82.

Радосављевић, М. и Ђорђевић, Б. (2016). Емоционална интелигенција запослених - елементи, развој и ефекти. Теме, 40(3), 1069-108.

Takšić, V., Mohorić, T., Munjaš, R. (2006). Emocionalna inteligencija: teorija, organizacija, primjena i povezanost sa pozitivnom psihologijom. Društvena istraživanja Zagreb, 4-5(84-85), 729-752.

Такшић, В. (2002). „Упитници емоционалне интелигенције (компетентности)“. У: К. Лацковић-Гргин, К., Баутовић, А., Чубела, В. и Пенезић, 3. (ур.), Збирка йсихолоїијских скала и уйийника. Задар: Филозофски факултет, 27-45.

Такшић, В. (2003). Скала емоционалне регулације и контроле (ЕРИК): провера факторске структуре. Психолоіијске йеме, 12, 43-54. 


\title{
STRUCTURE OF EMOTIONAL INTELLIGENCE AND LEADERSHIP OF THE STUDENTS OF THE FACULTY OF SECURITY STUDIES AND THE TEACHER EDUCATION FACULTY
}

\author{
Violeta Tadić, PhD Student \\ University of Belgrade, Faculty of Security Studies
}

\begin{abstract}
Summary
An appropriate sample of 169 subjects (students of the Faculty of Security Studies 58.6\%, and students of the Teacher Education Faculty 41.4\%) examined the connection between emotional intelligence and leadership. The emotional intelligence research was conducted using the following questionnaires: Emotional Intelligence Questionnaire, ECQ-45, ECQ-15 and ERCQ. Leadership research was conducted with questionnaires compiled by the authors and verified metric characteristics. Factor analysis isolated eight factors: Empathic understanding and support $(\alpha=.93)$, Knowing and managing emotions $(\alpha=.92)$, Emotional overwhelm $(\alpha=.86)$, Leadership $(\alpha=.89)$, Reading emotions $(\alpha=.85)$, Managing people $(\alpha=.69)$, Negative emotions striking $(\alpha=.65)$, and Striving for better action ( $\alpha=.66)$. Leadership positively correlates with three components of emotional intelligence: Empathic understanding and support $(\mathrm{r}=.56)$, Knowing and managing emotions $(r=.51)$, and Reading emotions $(r=.37)$, while with Emotional overwhelm builds a negative correlation $(r=-.30)$. No statistically significant differences were found between the students of the Faculty of Security Studies and the Teacher Education Faculty.
\end{abstract}

Keywords: emotional intelligence, leadership, negative emotions, empathy, reading emotions. 